\title{
Eosinophil cationic protein mRNA expression in children with bronchial asthma
}

\author{
H.Y. Yu' ${ }^{1}$, X.Y. Li ${ }^{2}$, Z.F. Cai ${ }^{1}$, L. Li ${ }^{3}$, X.Z. Shi ${ }^{4}$, H.X. Song ${ }^{5}$ and X.J. Liu ${ }^{1}$ \\ ${ }^{1}$ Department of Pediatrics, Qilu Hospital of Shandong University, Jinan, \\ Shandong, China \\ ${ }^{2}$ Qilu Children's Hospital, Shandong University, Jinan, Shandong, China \\ ${ }^{3}$ Department of Child Health Care, Qilu Hospital of Shandong University, \\ Jinan, Shandong, China \\ ${ }^{4}$ The First People's Hospital of Jinan City, Jinan, Shandong, China \\ ${ }^{5}$ Department of Pediatrics, the First Hospital Affiliated to Shandong \\ University of Traditional Chinese Medicine, Jinan, Shandong, China \\ Corresponding author: X.J. Liu \\ E-mail: shandongxinjie220@163.com
}

Genet. Mol. Res. 14 (4): 14279-14285 (2015)

Received March 16, 2015

Accepted June 9, 2015

Published November 13, 2015

DOI http://dx.doi.org/10.4238/2015.November.13.11

\begin{abstract}
Studies have shown that eosinophils are closely related to pathogenesis of bronchial asthma. Eosinophils release eosinophil cationic protein (ECP), which plays an important role in infection and allergic reactions. Serum ECP mRNA expression in children with bronchial asthma has not been adequately investigated. We analyzed serum ECP mRNA expression in 63 children with bronchial asthma and 21 healthy children by using reverse-transcriptase polymerase chain reaction to understand the role of ECP in children with bronchial asthma. The children with bronchial asthma were segregated into acutephase and stable-phase groups, based on the severity of the illness. Serum ECP mRNA expression in children with bronchial asthma $(0.375$ $\pm 0.04)$ was significantly higher than that in healthy controls $(0.20 \pm$ $0.02 ; \mathrm{P}<0.05)$. Additionally, children in the acute-phase group showed
\end{abstract}


higher ECP mRNA expression level $(0.44 \pm 0.06)$ than those in the stablephase $(0.31 \pm 0.03)$ and healthy control groups $(0.20 \pm 0.02 ; \mathrm{P}<0.05)$, while the level in the stable-phase $(0.31 \pm 0.03)$ was markedly higher than that in the healthy control group $(0.20 \pm 0.02 ; \mathrm{P}<0.05)$. Detection of serum ECP mRNA expression level has possible applications in the diagnosis and treatment of children with bronchial asthma.

Key words: Bronchial asthma; Children; Eosinophils; ECP; mRNA

\section{INTRODUCTION}

Bronchial asthma occurs mostly in children and adolescents and is mainly characterized by high airway reactivity, causing reversible airflow limitation. Symptoms include cough, dyspnea, and an expiratory wheezing sound, which can be alleviated with spasmolytics, antiasthmatics, or rest. However, some patients show serious symptoms, which can be life-threatening (Agodokpessi et al., 2014; Folmsbee et al., 2015). Recently, the incidence of bronchial asthma and resulting deaths has increased due to the impact of air pollution as well as environmental and lifestyle changes (Araújo et al., 2014). The pathogenesis of bronchial asthma is not clear. Current literature suggests that bronchial asthma is a type of chronic inflammatory respiratory system disease involving smooth muscle cells, neutrophils, airway epithelial cells, and eosinophils working together, while its pathogenesis is closely related to eosinophils (Zhang et al., 2015). Eosinophils secrete eosinophil cationic protein (ECP), which plays an important role in the incidence of infection and allergic response (Gao et al., 2014; Glover et al., 2014; Norback et al., 2014). Serum ECP mRNA expression in children with bronchial asthma has not been adequately investigated. In this study, we determined serum ECP mRNA expression levels in children with bronchial asthma.

\section{MATERIAL AND METHODS}

\section{Reagents}

RNA was extracted and reverse-transcriptase polymerase chain reaction (RT-PCR) was performed using kits by Sunbio company (Beijing, China). PCR primer was designed and synthesized by Sunbio company ScienBio (Beijing, China).

\section{Subjects}

\section{Children with bronchial asthma}

Serum specimens were collected from 63 children with bronchial asthma, consisting of 35 males and 28 females, with mean age of $10 \pm 2$ years, who visited the Department of Pediatrics at Qilu Hospital of Shandong University between April 2014 and October 2014. Diagnosis was performed as per standards published by the Global Initiative for Asthma (Bateman et al., 2008). This group included 44 cases in acute phase and 19 cases in stable phase of the disease. The clinical data in both acute versus stable phase groups were comparable. 


\section{Control group}

As the control group, 21 healthy children, 10 males and 11 females, with mean age of $11 \pm 3$ years, were enrolled from the physical examination center in the same period. The clinical data were comparable.

The study protocol was approved by the Research Ethics Committee at the hospital, and all patients provided informed consent before study commencement.

\section{Methods}

RT-PCR was used to determine serum ECP mRNA levels. Blood samples were collected in the morning and centrifuged at $3000 \mathrm{rev} / \mathrm{s}$ and stored at $-80^{\circ} \mathrm{C}$. RNA extraction was performed as per manual instructions. cDNA was synthesized using Invitrogen reverse-transcription kit Sunbio company (Beijing, China). The cycling conditions for RTPCR consisted of an initial, single cycle at $95^{\circ} \mathrm{C}$ for $2 \mathrm{~min}$, followed by 32 cycles of 60 $\mathrm{s}$ at $95^{\circ} \mathrm{C}, 60 \mathrm{~s}$ at $55^{\circ} \mathrm{C}$, and $60 \mathrm{~s}$ at $72^{\circ} \mathrm{C}$, after which $10 \mu \mathrm{L}$ PCR amplification product was used for electrophoresis and analyzed by statistical software. The following primers were used: ECP sense: 5'-GAAAGATGGGGCTGTTGAGT-3'; anti-sense: 5'-CTTCTCACCACGAGGTAGCG-3'; $\beta$-actin sense: 5'-ATTCCTATGTGGGCGAOGAG-3'; anti-sense: 5'-AGAGGC-GTACAGGGATAGCA-3'

\section{Statistical analysis}

All statistical analyses were performed using the SPSS18.0 software (Chicago, IL, USA). Differences between means were analyzed using the $t$-test, where $\mathrm{P}<0.05$ was considered as statistically significant result.

\section{RESULTS}

\section{Comparison of serum ECP mRNA levels in children with bronchial asthma vs healthy controls}

Serum ECP mRNA expression levels in children with bronchial asthma $(0.375 \pm 0.04)$ were significantly higher than those in healthy controls $(0.20 \pm 0.02)(\mathrm{P}<0.05$; Table 1$)$.

Table 1. Comparison of serum ECP mRNA levels in children with bronchial asthma $v s$ healthy controls.

\begin{tabular}{lcc}
\hline Group & Cases & ECP mRNA level \\
\hline Bronchial asthma group & 63 & $0.375 \pm 0.04$ \\
Healthy control group & 21 & $0.20 \pm 0.02$ \\
\hline P $<0.05$
\end{tabular}

\section{Comparison of serum ECP mRNA level in children with acute phase bronchial asthma vs those with stable phase bronchial asthma}

The children with bronchial asthma were further divided into acute-phase and stablephase groups. Children with acute-phase bronchial asthma showed visibly higher ECP mRNA expression levels $(0.44 \pm 0.06)$ than did those with stable-phase $(0.31 \pm 0.03 ; \mathrm{P}<0.05$; Table 2$)$. 
Table 2. Comparison of serum ECP mRNA levels in children with bronchial asthma in acute phase $v s$ those with bronchial asthma in stable phase.

\begin{tabular}{lcc}
\hline Group & Cases & ECP mRNA level \\
\hline Bronchial asthma group & 44 & $0.44 \pm 0.06$ \\
Healthy controls & 19 & $0.31 \pm 0.03$ \\
\hline $\mathrm{P}<0.05$ & &
\end{tabular}

\section{Comparison of serum ECP mRNA levels in children with stable bronchial asthma vs healthy controls}

Serum ECP mRNA levels in children with stable-phase bronchial asthma $(0.31 \pm$ $0.03)$ were markedly higher than those in healthy controls $(0.20 \pm 0.02 ; \mathrm{P}<0.05$; Table 3$)$.

Table 3. Comparison of serum ECP mRNA levels in children with stable bronchial asthma $v$ sealthy controls

\begin{tabular}{lcr}
\hline Group & Cases & ECP mRNA level \\
\hline Bronchial asthma group & 21 & $0.31 \pm 0.03$ \\
Healthy controls & 19 & $0.20 \pm 0.02$ \\
\hline
\end{tabular}

$\mathrm{P}<0.05$.

\section{Agarose gel electrophoresis of RT-PCR products}

Serum samples from children in acute-phase group exhibited stronger bands than did those from children in the stable-phase group, which in turn showed stronger bands than did those from the healthy controls (Figure 1).

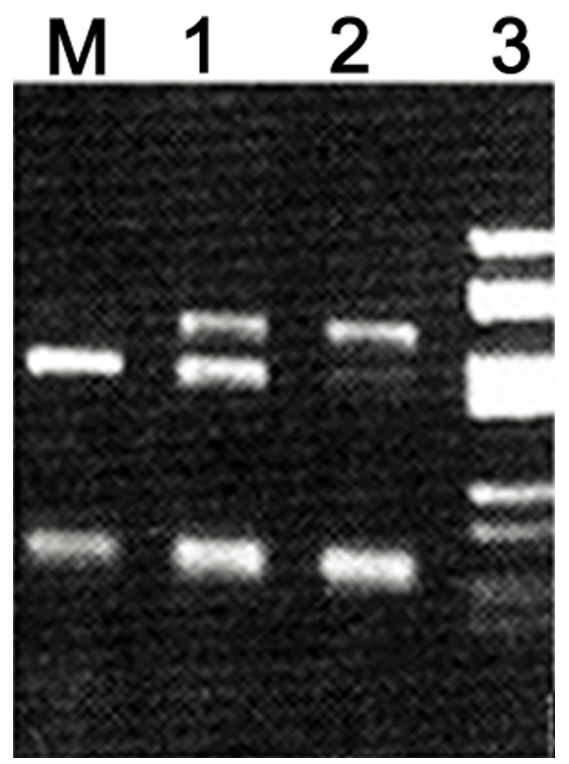

Figure 1. ECP mRNA electrophoresis. Lane $M$, marker; lane 1, control; lane 2, bronchial asthma in acute phase; lane 3 , bronchial asthma in stable phase. 


\section{DISCUSSION}

The etiology of bronchial asthma is still not fully elucidated. Previous studies have revealed that, in addition to infections caused by bacteria, viruses, and mycoplasma, environmental and genetic factors also play an important role in pathogenesis (Masid-de-Brito et al., 2014; Namjou et al., 2014; Martineau et al., 2015). Airway obstruction caused by bronchial asthma is reversible, while airway hyper-responsiveness and stimulation caused by inflammatory mediators are characteristic of bronchial asthma (Schoepf and Heun, 2014; Lozano et al., 2014; Gadhe, 2015; López-Expósito et al., 2015; Turner et al., 2015).

Several studies have indicated that eosinophils are widely distributed in the respiratory mucosa, mainly functioning to clear and engulf bacteria. ECP is a specific marker of eosinophils (Ursaciuc et al., 2010; Shah et al., 2012; Beigelman, 2014; Smith et al., 2015), which is mainly activated and released by eosinophils and causes neurotoxicity and cytotoxicity. In addition, ECP induces release of histamine by mast cells, causing airway hyperresponsiveness, resulting in bronchial asthma attack (Reed et al., 2007; Choi et al., 2010; Chua et al., 2010; Ursaciuc et al., 2010; Wei et al., 2010; Braga et al., 2011; Olive et al., 2011).

A previous study reported a comparison of serum ECP levels in 60 children with capillary bronchitis and 50 healthy controls, where children in acute phase exhibited visibly higher serum ECP mRNA expression levels than did those in stable phase as well as the healthy controls (Brightling et al., 2008). This indicated that ECP mRNA expression increases with increasing severity of the condition. Lee et al. (2003) reported that ECP mRNA was detected in induced sputum samples from 80 children with bronchial asthma and 62 normal controls by using chemiluminescence enzyme-linked immune assay. They found that ECP mRNA level in the sputum was significantly higher in children with acute-phase bronchial asthma than that in children with stable phase or in normal controls (Lee et al., 2003), suggesting that ECP mRNA in the sputum can reflect the severity of asthma.

Our results showed that children with acute-phase bronchial asthma showed obviously higher ECP mRNA expression levels than did those in the stable phase and healthy controls. Serum ECP mRNA expression levels in children with stable-phase bronchial asthma were markedly higher than those in healthy controls. This is in accordance with previous studies.

In summary, serum ECP mRNA expression levels can reflect the severity of bronchial asthma and thus, function as an effective indicator to monitor bronchial asthma. This suggests potential applications in the diagnosis and treatment of children with bronchial asthma.

\section{Conflicts of interest}

The authors declare no conflict of interest.

\section{ACKNOWLEDGMENTS}

We thank the anonymous reviewers for reviewing this manuscript.

\section{REFERENCES}

Agodokpessi G, Ade G, Dovoedo N, Ade S, et al. (2014). Sensitisation profile to airborne allergens of patients followed for asthma in Cotonou, Benin. A cross-sectional study using prick-tests. Rev. Mal Respir. [Epub ahead of print]. 
Araújo A, Rocha RL and Alvim CG (2014). Adolescence and asthma management: the perspective of adolescents receiving primary health care. Rev. Paul. Pediatr. 32: 171-176.

Bateman ED, Hurd SS, Barnes PJ, Bousquet J, et al. (2008). Global strategy for asthma management and prevention: GINA executive summary. Eur Respir. J. 31: 143-178.

Beigelman A, Isaacson-Schmid M, Sajol G, Baty J, et al. (2014). Randomized trial to evaluate azithromycin's effects on serum and upper airway IL-8 levels and recurrent wheezing in infants with respiratory syncytial virus bronchiolitis. J. Allergy Clin. Immunol. 135: 1171-1178.

Braga M, Quecchia C, Cavallucci E, Di Giampaolo L, et al. (2011). T regulatory cells in allergy. Int. J. Immun. Pharmacol. 24: $55 \mathrm{~S}-64 \mathrm{~S}$.

Brightling C, Berry M and Amrani Y (2008). Targeting TNF-alpha: a novel therapeutic approach for asthma. J. Allergy Clin. Immunol. 121: 5-10; quiz 11-2.

Choi J, Callaway Z, Kim HB, Fujisawa T, et al. (2010). The role of TNF-alpha in eosinophilic inflammation associated with RSV bronchiolitis. Pediatr. Allergy Immunol. 21: 474-479.

Chua KH, Puah SM, Chew CH, Tan SY, et al. (2010). Study of the CTLA-4 gene polymorphisms in systemic lupus erythematosus (SLE) samples from Malaysia. Ann Hum Biol. 37: 274-280.

Folmsbee SS, Morales-Nebreda L, Van Hengel J, Tyberghein K, et al. (2015). The cardiac protein alpha-T-catenin contributes to chemical-induced asthma. Am J. Physiol. Lung Cell Mol. Physiol. ajplung 00331.

Gadhe CG and Kim MH (2015). Insights into the binding modes of CC chemokine receptor 4 (CCR4) inhibitors: a combined approach involving homology modelling, docking, and molecular dynamics simulation studies. Mol. Biosyst. 11: 618-34.

Gao W, Cai L, Xu X, Fan J, et al. (2014). Anti-CTGF Single-Chain Variable Fragment Dimers Inhibit Human Airway Smooth Muscle (ASM) Cell Proliferation by Down-Regulating p-Akt and p-mTOR Levels. PLoS One 9: e113980.

Glover G, Connolly B, Di Gangi S, Lisa Ayers, et al. (2014). An observational cohort study to determine efficacy, adherence and outcome of the early initiation of pressure support ventilation during mechanical ventilation. $B M J$ Open Respir. Res. 1: e000028.

Lee SW, Song JH, Kim GA, Lim HJ, et al. (2003). Plasma brain natriuretic peptide concentration on assessment of hydration status in hemodialysis patient. Am J. Kidney Dis. 41: 1257-1266.

Lopez-Exposito I, Srivastava KD, Birmingham N, Castillo A, et al. (2015). Maternal Antiasthma Simplified Herbal Medicine Intervention therapy prevents airway inflammation and modulates pulmonary innate immune responses in young offspring mice. Ann Allergy Asthma Immunol. 114: 43-51 e1.

Lozano J, Cruz MJ, Piquer M, Giner MT, et al. (2014). Assessing the efficacy of immunotherapy with a glutaraldehydemodified house dust mite extract in children by monitoring changes in clinical parameters and inflammatory markers in exhaled breath. Int. Arch. Allergy Immunol. 165: 140-147.

Martineau AR, James WY, Hooper RL, Barnes NC, et al. (2014). Vitamin D supplementation in patients with chronic obstructive pulmonary disease (ViDiCO): a multicentre, double-blind, randomised controlled trial. Lancet Respir. Med. 3: 120-30.

Masid-de-Brito D, Queto T, Gaspar-Elsas MI and Pedro XE (2014). Roles of 5-lipoxygenase and cysteinyl-leukotriene type 1 receptors in the hematological response to allergen challenge and its prevention by diethylcarbamazine in a murine model of asthma. Med. Inflamm. 2014: 403970.

Namjou B, Marsolo K, Caroll RJ, Denny JC, et al. (2014). Phenome-wide association study (PheWAS) in EMRlinked pediatric cohorts, genetically links PLCL1 to speech language development and IL5-IL13 to Eosinophilic Esophagitis. Front. Genet. 5: 401.

Norback D, Lampa E and Engvall K (2014). Asthma, Allergy and Eczema among Adults in Multifamily Houses in Stockholm (3-HE Study) - Associations with Building Characteristics, Home Environment and Energy Use for Heating. PLoS One 9: e112960.

Olive D, le Thi S, Xerri L, Hirsch I, et al. (2011). The role of co-inhibitory signals driven by CTLA-4 in immune system. Med. Sci. 27: 842-849.

Reed KL, Heydrick SJ, Aarons CB, Prushik S, et al. (2007). A neurokinin-1 receptor antagonist that reduces intraabdominal adhesion formation decreases oxidative stress in the peritoneum. Am J. Physiol. Gastrointest. Liver Physiol. 293: G544-551.

Schoepf D and Heun R (2014). Anxiety disorders and physical comorbidity: increased prevalence but reduced relevance of specific risk factors for hospital-based mortality during a 12.5-year observation period in general hospital admissions. Eur. Arch. Psychiatry Clin. Neurosci. 265: 387-398.

Shah MM, Saio M, Yamashita H, Tanaka H, et al. (2012). Lactobacillus acidophilus strain L-92 induces CD4(+)CD25(+) Foxp3(+) regulatory T cells and suppresses allergic contact dermatitis. Biol. Pharm. Bull. 35: 612-616. 
Smith GE, Bawa Z, Macklin Y, Roger M, et al. (2015). Using real-time syndromic surveillance systems to help explore the acute impact of the air pollution incident of March/April 2014 in England. Environ Res. 136: 500-504.

Turner PJ, Gowland MH, Sharma V, Ierodiakonou D, et al. (2014). Increase in anaphylaxis-related hospitalizations but no increase in fatalities: An analysis of United Kingdom national anaphylaxis data, 1992-2012. J. Allergy Clin. Immunol. 135: 956-963.

Ursaciuc C, Surcel M, Ciotaru D, Dobre M, et al. (2010). Regulatory T cells and TH1/TH2 cytokines as immunodiagnosis keys in systemic autoimmune diseases. Roum. Arch. Microbiol. Immunol. 69: 79-84.

Wei W, Liu Y, Wang Y, Zhao Y, et al. (2010). Induction of CD4+CD25+Foxp3+IL-10+ T cells in HDM-allergic asthmatic children with or without SIT. Int. Arch Allergy Immunol. 153: 19-26.

Zhang F, Huang G, Hu B, Li-Ping Fang, et al. (2015). Recombinant HMGB1 A box protein inhibits Th17 responses in mice with neutrophilic asthma by suppressing dendritic cell-mediated Th17 polarization. Int Immunopharmacol. 24: 110-118. 